P-ISSN: 2774-4574; E-ISSN: 2774-4582

TRILOGI, 2(3), September-Desember 2021 (220-227)

@2021 Lembaga Penerbitan, Penelitian,

dan Pengabdian kepada Masyarakat (LP3M)

Universitas Nurul Jadid Paiton Probolinggo

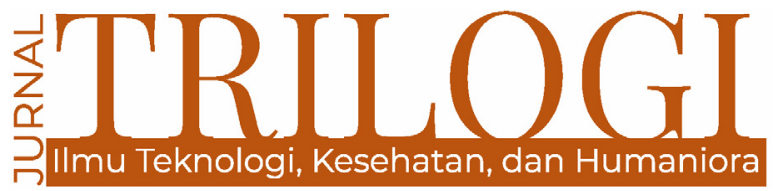

\title{
FILM INDUSTRY AS PART OF GLOBAL CREATIVE INDUSTRY: LEARNING FROM INDONESIA
}

\section{Mohammad Bahrul Ulum}

Universitas Nurul Jadid, Probolinggo, Indonesia

masrurul@unuja.ac.id

\section{Faizzatul Jannah}

Universitas Nurul Jadid, Probolinggo, Indonesia

\section{Fikriyatun Nadhiyah}

Universitas Nurul Jadid, Probolinggo, Indonesia

\begin{abstract}
This paper describes the post-reform Indonesian film industry as one of the creative industry sub-sector. The creative industry has contributed to developing a city and a country to increase the market and the global economy. Creative industries have great potential to boost the economy and the quality of life of the Indonesian people. The international film industry can obtain revenue up to $\$ 10,162,657,657$ (approximately IDR 980 trillion), with ticket sales reaching $1,276,715,780$ pieces and the number of moviegoers went more than a 700million people. Meanwhile, in Indonesia, according to research by Oxford Economics, considering the direct and indirect transactions caused, the total economic contribution of the film and television industry to GDP in 2010 reached USD 2.98 billion or 0.43 percent of all national GDP. This study aims to analyze three sub-sectors of the film industry, namely production, distribution, and exhibition, as well as to describe how the conditions in the national film industry in the post-reform era since the film industry was lined up as one of the sub-sectors of the creative industry.
\end{abstract}

Keywords: Indonesian film industry, creative industry, independent film 


\begin{abstract}
Abstrak
Tulisan ini memaparkan industri perfilman Indonesia pasca reformasi sebagai salah satu subsektor industri kreatif. Industri kreatif telah berkontribusi dalam mengembangkan kota dan negara untuk meningkatkan pasar dan ekonomi global. Industri kreatif memiliki potensi besar untuk mendongkrak perekonomian dan kualitas hidup masyarakat Indonesia. Industri film internasional dapat memperoleh pendapatan hingga \$10.162.657.657 (sekitar Rp 980 triliun), dengan penjualan tiket mencapai 1.276.715.780 buah dan jumlah penonton bioskop mencapai lebih dari 700 juta orang. Sementara di Indonesia, menurut penelitian Oxford Economics, dengan mempertimbangkan transaksi langsung dan tidak langsung yang ditimbulkan, total kontribusi ekonomi industri film dan televisi terhadap PDB tahun 2010 mencapai USD 2,98 miliar atau 0,43 persen dari seluruh PDB nasional. Penelitian ini bertujuan untuk menganalisis tiga subsektor industri perfilman yaitu produksi, distribusi, dan eksibisi, serta mendeskripsikan bagaimana kondisi perfilman nasional pasca reformasi sejak industri perfilman dijajarkan sebagai satu kesatuan. subsektor industri kreatif.
\end{abstract}

Kata kunci: industri film Indonesia, industri kreatif, film independen

\section{Introduction}

Throughout the year, the filming process takes place all over the world. VariousFilm genres are produced using a variety of technologies and cinematic techniques. The film then becomes a reflection of the nation's culture and a medium of the symbolic condition of the social order of a country. The film is the result of work collectively, which in other words, the process of making a film must involve the creation of several elements or professions, such as producer, director, screenwriter, camera engineer, stylist artists, music directors, editors, performers and sound engineers, as well as actors.

Since the beginning of the 19th century, in 1888, when Thomas Alfa Edison invented the machine the first cinema named cinematography, the world film industry has continued to grow. Initially, French film productions became the motor of the world film revival, marked by Charles Pathe's first colossal film. However, after World War 1 ended, the Hollywood film industry dominated the world film market. The six most significant film studios world, born in the United States, Warner Bros. Pictures (1923), MetroGoldwyn-Meyer(1924), Radio-Keith-Orpheum (RKO, 1928), 20th Century Pictures Company (1933), Paramount Pictures (1935) and includes Walt Disney Pictures, which house touchstone Picture, Pixar Animation Studio, and Marvels Studio.

Thousands of films are produced every year. The today development of the film industry is not only Hollywood. India is the most productive country in manufacturing films, naming the industry Bollywood - a combination of Bombay and Hollywood. Meanwhile, Nigeria is building a film industry alternative to Nollywood in other parts of the world. However, China is mentioned as one of the fastest-growing film markets. For example, in the second week of February 2016, China's office's total revenue box reached 548 million US dollars, equivalent to Rp. 7.4 trillion, according to The Hollywood Reporter, the amount of revenue surpassed a record North American box office earnings when Star Wars: The Force Awakens was released, with income from December 26 to January 1 only reaching 529.6 million dollars USA (Della, 2016). The film itself, apart from being an economic commodity, also functions as a means of lighting ( entertainment ), education (education), and entertainment (recreation). On the side today, with the convergence of technology and the development of digital technology, industry world film has become part of the creative industry.

The film is one of the creative industries because it has excellent potential in creative economy development. Sheila Timothy, the producer of Lifelike Pictures, the chairman of the Indonesian Film Producers Association (Aprofi), said that films are objects culture with economic value. Films look like soft power but superpower(Rulianto, 2013). A film with two innate characters, culture and economy, which cannot beIt is this integral part makes the film so powerful. One example of the most tangible and actual embodiment is Hollywood blockbuster films with high economic value (famous actors, large production scale, exciting stories, beautiful visual effects, soundtracks from famous musicians, 
and so on). Its high market penetration is very aggressive. On the other hand, these Hollywood blockbusters also contain values cultural values (way of life, customs, values and norms, ideology, to political and cultural culture), etc.) which is then able to penetrate well into the minds of the audience from other countries (Rulianto, 2013). The presence of cultural values in this film Hollywood is often used to show its power and efforts to dominate world politics and security.

Film as a cultural product has an essential role in delivering local cultural messages. As is the case in Hollywood and other parts of the world, Indonesiahimself once harnessed the cultural and economic power of film during the era of Suharto's leadership to strengthen the capacity of the New Order for 32 years year. For example, the G30S PKI and Janur Kuning films tell about leadership Suharto, who is described as a hero of the nation, a defender of the indigenous people, and a fair leader. Since the Soeharto era ended, the Indonesian film industry has continued to grow. The depiction of local culture and film as media means of conveying political and cultural messages as a tool for permanent economic activists emerged in the Indonesian film industry today. However, the variety of films' genres, products, and service types become more diverse and accessible in expressing ideology filmmakers.

\section{Indonesian Creative Industry}

Interest in creative industries has grown among advanced countries, developed countries, and developing countries. The creative economy is a concept that places creativity and knowledge as the main asset in driving the economy. The big message that the creative economy offers is the use of resource reserves that are renewable, even unlimited, namely ideas, talents, and creativity (Indonesia Design Team) Power - Ministry of Commerce, 2008: 1). The creative economy is considered to provide many positive contributions to developing a city and even a country to improve global markets and economy.

The number of countries that apply the creative industry is significantly higher and provides more excellent stability into the future; thus, the concept of creative industries has been successfully integrated into both developed countries' policy agendas and is growing. The government began to develop specific strategies and policies to promote them. The creative industry is one of the fastest developing sectors in the world. The average annual growth of the creative industries globally reaches between 5 and $20 \%$ (Simatupang et al., 2012). In some cases, increasing revenue from the creative industry sector got higher than the increase in the country's overall economy.

Some countries are famous for their success in developing creative industries. The Manchester Institute for Popular Culture (www.mmu. ac.uk/h-ss/mipc) has identified innovative industry initiatives in the cities of Barcelona (Spain), Goteburg(Denmark), Milan (Italy), Jämtland (Sweden), Tilburg (Netherlands), Berlin (Germany), Helsinki(Finland), and Dublin (Ireland) (Flew, 2002). Cunningham (2009) identified some variations on the "creative industry theme as it has traveled in around the world" and points to differing emphases and outcomes in the United States, Europe, Asia, China, Australasia, and the Global South (Ashton, 2013). Meanwhile, in East Asia, the governments of Singapore and Malaysia are pioneers in developing infrastructure network broadband through the Multimedia Super Corridor (MSC) and 'Smart Island' initiatives(Flew, 2002).

The term creative industry emerged in the early 1990s in Australia, coined byHowkins, while other business scholars claim that sector took place in England in 1997. The creative economy was introduced globally by John Howkins through the book "The Creative Economy: How People Make Money from Ideas" in 2001. Howkinsrealized the birth of a new wave of the creativity-based economy after looking at 1997. The United States produces products Intellectual Property Rights (IPR)worth 414 Billion Dollars, making IPR the number 1 export of the United States. Howkins ago briefly defines the creative economy as:

"Economic activity in society that takes up most of the time to generate ideas, not just do things that are routine and repetitive. Because for this society, generating ideas is the thing to do for progress."

Meanwhile, the latest Creative Economy Study conducted by the United Nations Conference on Trade and Development (UNCTAD) in 2010 defined the Creative Economyas: "An evolving concept based on creative assets potentially generating economic growth and development ." With further described as follows:

1. Drive income generation, job creation, and income exports while promoting social awareness, cultural diversity, and human development.

2. Enclose aspects of social, culture, and economy in technology development, 
Intellectual Property Rights, and tourism.

3. A collection of knowledge-based economic activities with dimensions development and cross-sectoral connectivity at the microeconomic level and macro as a whole.

4. A choice of a development strategy that requires crossactioninnovative and multidisciplinary ministries and policies.

5. At the heart of the Creative Economy lies the Creative Industry.

Related to the popularity of the creative industry, now, the definition of the creative industry is seen from various points of view. UK Department of Culture, Media and Sport defines creative industries as those industries which have their origins in individual creativity, skills, and talents and who have the potential for wealth and job creation through the generation and exploitation of intellectual property (Carr, 2009; Cunningham, Potts, Hartley, \& Ormerod, 2005;. Durmaz et al., 2010; Fly, 2002; Higgs \&Cunningham, 2008; Simatupang et al., 2012). Similarly, O'Connor (2009, p. 366)shows that "creative industries" can be understood as "typical grouping economics, frameworks for conjoining certain types of intellectual labor or artistic, or simply in the form of a constructive policy" (Ashton, 2013). ThereforeTherefore, both definitions point to the development of human capital as limited resource resources and intellectual property.

In another definition, according to Howkins, the creative industry is defined as the definition of new analytics of the industrial component of the economy where creativity is input and content, or intellectual property is the output (Potts \& Cunningham, 1998). He states that the term "creative industries" should apply to any industry in which"The power of human creativity is more significant and where the result is wealth"intellectual property (Galloway \& Dunlop, 2007). Howkins underscores the creative process and intellectual property to describe the creative industry. On the other hand, the perspective that Scott (2000) mentioned represents the creative industries characterized with the output of commercialized products with high aesthetic and symbolic content. It reflects the tendency of creative production to become a higher commodity, while the commodity of creativity itself is becoming increasingly invested with value symbolic (Chen, 2012). Scoot shows innovative products as a marker of creative industries.
The definition of the scope of the creative industry generally includes innovative products (i.e., art, performance, visual arts, crafts, design, fashion designer, film, leisure software interactive, music, and TV and radio) and creative services (i.e., advertising, architecture, publishing, cultural facilities, and computer software and services) (Chen, 2012; Simatupang et al., 2012). Along with the development of digital technology, the creative industry sub-sector and product specifications with digital content products. Digital content and apps generated by the creative industries, including the output of the computer game industry, websites web, digital video art, and digital film and television production including text, graphics, special effects, animation, and post-production, in the areas of new media, music, architecture, and design, and education and health (DCITA 2001 as mentioned by Flew,2002). Although scholars, the sub-sector develop, categorize the creative industry sub-sector according to the needs of each country. Multiple sectors accommodate cultural values more than any other sector. These cultural values make the creative industry inIt is essential to maintain local identity.

In Indonesia itself, in the National Creative Economy Development Blueprint 2009-2015 (2008), the creative economy is defined as: "A new era of economics after the economy agriculture, industrial economics, and the information economy, which intensifies information and creativity by relying on ideas and knowledge from human resources as the main factor of production in its economic activity. While the definition of the Creative Industry in Indonesia as written in the Blueprint for the Development of the National Creative Economy2009-2015 (2008) are: "Industry originating from the use of creativity, skills and individual talents to create wealth and jobs through creation and utilization of the creative and creative power of the individual." Economic creatives contributed to Gross Domestic Product (GDP) $7.38 \%$ of the total financial contribution national economy in 2015. During 2010-2015, the creative economy sector's gross domestic product (GDP) increased from Rp525.96 trillion to Rp852.24 trillion (Margrit, 2016). The creative economy contributes 12 million people to the total national labor force, which is temporary, related to the absorbed labor force. These numbers show that Indonesia's creative industry contributes to GDP, and the number of workers interested looks significant. The creative economy has great potential to improve the economy and the quality 
of life of the Indonesian people.

The Ministry of Trade of the Republic of Indonesia maps out 15 areas of the creative economy-not much different from mapping in other countries and other world organizations. In 2007, the Ministry of Trade of the Republic of Indonesia defined industry creative as an industry that comes from the use of creativity, skills, and talented individuals to create wealth and jobs through the creation and utilization of the individual's creative and creative power (Indonesia Design Power Team)- Ministry of Commerce, 2008: 4). The 15 fields of Indonesia's creative economy are advertising, architecture, arts, crafts, design, fashion, video, film and photography, interactive games, music, performing arts, publishing and printing, services computers and software, television and radio, research, and development, and culinary arts. Each of these creative industry sub-sectors.

Cultural content on creative industry products is a new way for the country and cities to become more competitive in the global economic era. People who consume more culture and experience in various creative forms impact the high growth rate of sales of cultural products (Nielsen, 2009). Economic experiences with cultural identity and social influence are essential components of the new consumption economy (Cunningham et al., 2005). Based on financial reports, the creative industry has a role in forging a national identity in maintaining local culture. Culture is the seed of image and identity, and local community cultural assistance forms identity-both individual and collective(Nielsen, 2009). In the creative industry, this culture is often expressed as a form of lifestyle, which in turn is shaped by works of art (film, music, theater, etc.).

In globalization, the mass media are essential parties for national identity. However, according to Robertson's theory, some scholars also say that globalization cannot be interpreted as creating global culture; there is no opportunity for different cultures to interact on a worldwide scale (Ashton, 2013). Some experts even further emphasize the importance of the media and consider mass media as a significant player in globalization. Rap (1997) describes the media as mere instruments, not as identity in itself, which could compete with the national government related to its power and influence to change the nature and essence of human society (Ashton, 2013). Film as a mass medium can be a tool for strengthening local content in innovative industrial products.

\section{The Indonesian Film Industry as One of the Sub-Sectors of the Indonesian Creative Industry}

The first film in Indonesia, screened in 1900 in Batavia, since then film been increasingly popular with Indonesia's people and has become one of the popular entertainment in Indonesia Indonesia. Cinemas are starting to appear in big cities in Indonesia; it is noted300 cinemas were established in Indonesia from 1900 to 1942. Meanwhile, in1926, Indonesia produced its first film entitled Loetoeng Kasaroeng, directed by Java Film Company. Until independence day, the Indonesian film industry was fronted by foreign workers in Indonesia -primarily European and Chinese nationals, while natives held only a tiny part of the role. In 1950, the film industry in Indonesia was owned by the natives, where Usmar Ismail produced the film Blood and Prayer. In 1950 , this was recognized as the initial milestone in founding the Indonesian film industry. The first day of shooting for the film Blood and Prayer was inaugurated as the day national film by the New Order government. Thus, officially the Indonesian film industry is believed to have started in 1950.

More than 67 years later, the Indonesian film industry is still alive, experiencing ups and downs in its development. Have you ever had a time? Glory in the 1970s until the period of decline was even considered almost died in the 1990s, various factors influenced the Indonesian film industry. IndustryIndonesian films in 2006 contributed $0.24 \%$ (approximately IDR 250 billion) to GDP contribution (Indonesia Design Power Team - Ministry of Trade, 2008: 10). On the other hand, in the same year, the sub-sector of the film, video, and creative photography industries has labor productivity is above the average with IDR 53,163 million/worker per year (TimIndonesia Design Power - Ministry of Commerce, 2008: 13). Increase in year-the following year based on studies conducted by consulting and research institutionsOxford Economics, taking into account the direct and indirect transactions that generated, the total economic contribution of the film and television industry to GDP in 2010reached USD 2.98 billion or 0.43 percent of the entire National GDP. These phenomena showed a significant increase from only $0.24 \%$ in 2006 . While in 2012, the film and television industry contributed USD845.1 million to the country's economy and was able to create 191 thousand jobs. 
One of the unique things about the existence of the Indonesian film industry is that theThis was dominantly influenced by government policies related to the film industry at that time concerned. In addition, the development of the Indonesian film industry is also influenced by economic, political, and technological developments in society. Indonesian film industry The last two decades have shown significant evolution compared to the previous era of government, even more so after2005, when the film was included as one of the sub-sectors of Indonesia's creative industry. This matter shows that national cinema is no longer considered political tools and economy but also a culture. Films can be explained through the management chain,industry-related products, and regulations.

The management chain of the Indonesian film industry consists of the production, distribution, and distribution chain exhibition. The production chain starts from searching for funds/investments to films ready to be watched. There is a creative process in the production chain from filmmaking: all crews, finance companies/investors, production houses, tool rental companies, and post-production houses involved in film-making (Effendy, 2008: 2). In contrast, the film distribution chain is an "invisible art," as it goes entirely behind the scenes, away from the hustle and bust reproduction and public spotlight at the exhibition stage (Sasono et al., 2011: 191). Company film distribution or distributors play a significant role in distributing films from producers to the cinema, television, and home video networks (DVD and VCD) (Effendy, 2008: 2). While the exhibition is the estuary of a series of supply management (supply chain).management), where audiences consume film products in various outlets different such as shows in theaters in the country (as well as abroad), videos on the home, television (cable and terrestrial) (Sasono et al., 2011: 275). The exhibition chain is usually held by cinema groups with thousands of screens at the end spear so that the output of the production chain can be enjoyed by moviegoers (Effendy,2008: 2).

The film production chain in Indonesia looks at the source element funding/capital, namely sponsored films, built-in, cross-promotion, terrestrial TV, private investors, and co-productions that fall into the type of commercial funding. Meanwhile, in the distribution chain of the adult film industry in Indonesia, only two entities play in the film industry, namely producers and importers -both of which are counted as film owners - and the second is cinema. As for the exhibition chain, the network group 21, a distributor and importer, also holds dominance over the space exhibition - in this case, commercial cinemas in Indonesia for the last decades, new then appeared BlitzMegaplex in 2006 Cinemaxx in 2012 as competitors.

With films as part of the creative economy, the implication is, films, of course, attract big investors to get involved in the industry as a business benefit from the world film business (Putri, 2013). Indie labels and significant labels then appear in the industry, representing a film with several different characteristics. These two concepts have always been two distinct phenomena, and essential brands will produce mainstream films that are just for profit, while indie labels produce more romantic films. Suppose the mainstream movie is a film where funding requires large numbers that always calculate production costs with all the advantages and disadvantages. In that case, independent film is assumed to be a film made, not solely relying on adequate funding big, preferring the material or the film's screenplay. Thus the industry Indonesia films are formed from mainstream film production, independent film production, national cinema chains, film production houses, independent film communities, and independent film festivals.

The image below describes the Indonesian film industry divided intoIndonesia's mainstream film industry and independent films seen from the three chains.

Figure 1. Indonesian Film Industry

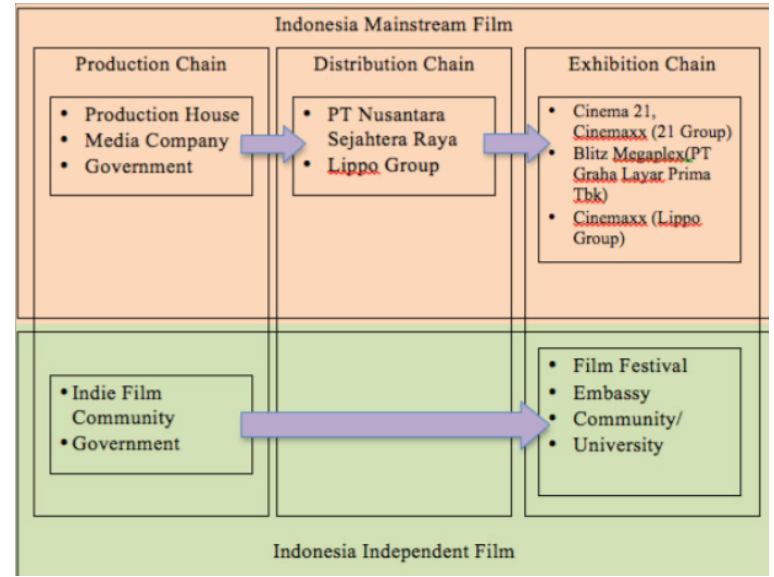

It can be seen that from the picture, Indonesian industrial films are included in the oligopoly industrial system, where there are only a few players in the film chain, even just one player on the film chain to another. Old 
names since the Suharto era still dominated the mainstream film industry in Indonesia. Meanwhile, Indonesian independent films are dominated by film communities that independently develop independent films as an alternative quality spectacle for the people of Indonesia. Independent films are also fronted by filmmakersYoung creative filmmakers who are romantic and willing to take risks to make independent films that are often unattractive commercially.

\section{Independent Films in the Indonesian Film Industry}

As in other parts of the world, the Indonesian film industry is experiencing the euphoria of the spirit of making do-it-yourself films or, more often, equating them with the term independent film. In Indonesia, the term independent film is often associated with short films. On the other hand, independent films are also not always of duration. In other words, there is a fundamental difference between a short film and a short independent film (Putri, 2013). If you look at the characteristics of the management chain, the genre of the film, and the regulation of independent films, Indonesia's independent films become easier identified based on the exhibition space carried out, budget sources, and the budget required for filming. Independent films are cheap films made with a budget of under IDR 1 billion, obtain non-which can generally be obtained from donor agencies, film endowment agencies, individuals with noncommercial funding logic, or Corporate Social programs corporate responsibility. Independent films are also defined as films that use alternative exhibitions and participating films at film festivals(Princess, 2013). On the other hand, independent films must also raise the theme of content local/regional culture, non-commercial, reflecting the community's actual conditions or even providing criticism on the state of the nation, and represent the spirit of change.

The fall of President Suharto's regime (19661998) in May 1998 became a momentum the rise of the Indonesian film industry in general and independent films in particular. This case is because the film Kuldesak can be categorically labeled as an independent film that has brought the wind of change to the Indonesian film industry. Kuldesak (Riri Riza et al., 1997) managed to enter the 21 Cineplex cinema network even though this film was made without registering the film's production plan with the Ministry of Education. The director has not yet obtained mandatory membership in the same agency (which requires the director to be an assistant director at least five times; Heeren, 2012, p. 21in Putri 2013). Kuldesak was labeled by the press as an 'independent film' and the beginning of the revival of the Indonesian film industry. This film was made with generous funds, a minimum of IDR 600 million, excluding promotional funds that reach IDR 150-200 million (all directors and cast are unpaid, including music director). Still, Kudesak succeeded in presenting 130,000 viewers out of 10,000 targeted viewers (Putri, 2013).

Indonesian independent films continue to grow. One of the important markers significant is the emergence of various independent film communities and film festivals both nationally and internationally. More and more film community, independent and productive, continues to produce films that can achieve multiple national and international awards. From 1999 until now, there have been dozens of festivals held by independent Indonesian film activists.

In 1999, 2000, 2001, 2002, 2006, 2007, 2008, 2009, and 2010, for example, the independent Video Film Festival (FFVII) was later renamed the Film FestivalShort Konfiden in 2006 was held. In 1999, JiFFest(Jakarta International Film Festival) was born first in the same year. JiFFest has never been absent from 1999 to 2010 . Still, in the same year, it was also held Europe Screen by European cultural centers, European institutions, and European Embassies. The festival was initially organized under the name European Film Festival (1999 and2003) by being a part of JiFFest (2004, 2005, and 2006). Then the festival using the name Europe on Screen since 2007 by been held independently(Princess, 2013). Other festivals are OK. Video - Jakarta International Video Festival (now called OK. Video: Jakarta International Video Festival ) was held by Ruang Rupa in Jakarta. Other festivals include the Animated Film FestivalIndonesian, Q! Film Festival Jakarta, Yogyakarta Documentary Film Festival, HelloFest Jakarta and iNAFF (Indonesia International Fantastic Film Festival), Documentary Film Festival (FFD)Yogyakarta, Q! Film Festival, iNAFF, Jogja-NETPAC Asian Film Festival (JAFF), a festival international films organized by JAFF in collaboration with NETPAC (Network for The Promotion of Asian Cinema) and other national-scale festivals that are organized by the local film community in certain cities, such as the Film Festival Purbalingga, Solo Film Festival, Malang Film Festival, Bali Documentary 
Film Festival,Cianjur Film Festival, Golden LensInternational Documentary Film Festival, Film FestivalStudents (Putri, 2013).

The condition of Indonesia that is experiencing changes in terms of politics and economy resulted in the formation of Indonesian independent films today. Indonesian independent film is also described by the three industrial film chains, production chains, distribution, and exhibition. Unlike the mainstream film industry, the chain is managed independently by an independent community. No wonder if the independent movie Indonesia represents cultural identityIndonesia better in the end. During the New Order era, Indonesian independent cinema was represented by films suburbs that don't show on commercial movie theater chains but triumph at international festival films. Now, Indonesian independent cinema also involves films capable of displaying on mainstream cinema networks and produced by filmmakers interested in the mainstream film industry. This situation resulted in Indonesia's independent cinema as an inseparable part of the national film industry.

\section{Conclusion}

The Indonesian film industry as part of the creative industry sub-sector can be mapped through the concept of chain management consisting of production, distribution, and exhibition chains. The film production chain in Indonesia looks at the elements of funding/ capital sources, namely sponsored films, builtin, cross-promotion, terrestrial TV, private and co-investors production, which is included in the type of commercial funding. While funding through donor agencies, film endowment institutions, individuals, customer relationship management, government agencies, and quasi-government are types of supporting non-commercial. While the other forming component in the film industry's production chain is the technology usedtechnological aspects of filmmaking include drawing, sound, editing, and finishing.

\section{References}

Ashton, D. (2013). Media work and the creative industries Identity work, and professionalism. http://doi.org/10.1108/ 004 00911111159494

Baskin, Askurifai. (2002). Peranan Perkembangan Film Indie terhadap Bangkitnya Film
Nasional. Jurnal Komunikasi Mediator. Bandung: Universitas Islam Bandung.

Chen, C. (2012). A multiple criteria evaluation of creative industries for the cultural creativity centre in Taiwan. http://doi. org/10.1108/13552550910983031

Cunningham, S., Potts, J., Hartley, J., \& Ormerod, P. (2005). Social network markets : A new definition of the creative industries, 1-26.

Della, Mia Vita. (2016). Seminggu Raup Rp 7 Triliun, China Patahkan Rekor Box Office Dunia. Mutila.com. Diakses pada 2 Maret 2016 di http://www.muvila.com/film/ artikel/seminggu-raup-rp-7-triliun-chinapatahkan-rekor- box-office-dunia-160218z. html.

Effendy, Heru. (2008). Industri Perfilman Indonesia: Sebuah Kajian. Jakarta: Erlangga.

Flew, T. (2002). Beyond ad hocery: Defining Creative Industries, 1-30.

Galloway, S., \& Dunlop, S. (2007). A Critique of Definitions of the Cultural and Creative Industries in Public Policy. International Journal of Cultural Policy, 13(1), 17-31. http://doi.org/10. 1080/ 10286630701201657

Margrit, Annisa. (2016). Kontribusi Ekonomi Kreatif Mulai Aktif. Koran Bisnis.com. Diakses pada 2 Maret 2016 di http://koran. bisnis.com/read/20161209/430/610663/ kontribusi- ekonomi-kreatif-mulai-aktif

Nielsén, T. (2009). THE CREATIVE INDUSTRIES - IMPLICATIONS FOR, (May), 1-21.

Potts, J., \& Cunningham, S. (1998). Four models of the creative industries.

Putri, Idola Perdini. (2013). Mendefinisikan Ulang Film Indie: Deskripsi Perkembangan Sinema Independen Indonesia. Jurnal Komunikasi Indonesia. Universitas Indonesia: Jakarta.

Rulianto, Angga. (2015). Kekuatan Dahsyat Film: Budaya dan Ekonomi. Mutila.co. Diakses pada 1 Maret 2016 di http://www.muvila. com/film/artikel/kekuatan-dahsyat-filmbudaya-dan-ekonomi-150907p.html.

Sasono, Eric et. al.. (2011). Menjegal Film Indonesia: Pemetaan Ekonomi Politik Industri Film Indonesia. Jakarta: Rumah Film Indonesia \& Yayasan Tifa.

Simatupang, T. M., Rustiadi, S., \& Situmorang, D. B. M. (2012). Chapter 5 Enhancing the Competitiveness of the Creative Services Sector in Indonesia, (March), 173-270. 